\title{
Editorial
}

\section{Latest Advances on Synthesis, Purification, and Characterization of Peptides and Their Applications}

\author{
Ayman El-Faham 1,2,*(D), Beatriz G. de la Torre ${ }^{3,4, *(\mathbb{D})}$ and Fernando Albericio $4,5,6, *$ (D) \\ 1 Department of Chemistry, College of Science, King Saud University, P.O. Box 2455, \\ Riyadh 11451, Saudi Arabia \\ 2 Chemistry Department, Faculty of Science, Alexandria University, P.O. Box 426, Ibrahimia, \\ Alexandria 12321, Egypt \\ 3 KwaZulu-Natal Research Innovation and Sequencing Platform (KRISP), School of Laboratory Medicine and \\ Medical Sciences, College of Health Sciences, University of KwaZulu-Natal, Durban 4041, South Africa \\ 4 Peptide Science Laboratory, School of Chemistry and Physics, University of KwaZulu-Natal, \\ Durban 4001, South Africa \\ 5 Institute for Advanced Chemistry of Catalonia (IQAC-CSIC), 08034 Barcelona, Spain \\ 6 CIBER-BBN (Networking Centre on Bioengineering, Biomaterials and Nanomedicine) and Department of \\ Organic Chemistry, University of Barcelona, 08028 Barcelona, Spain \\ * Correspondence: aymanel_faham@hotmail.com (A.E.-F.); garciadelatorreb@ukzn.ac.za (B.G.d.1.T.); \\ albericio@ukzn.ac.za (F.A.)
}

check for

updates

Citation: El-Faham, A.; de la Torre, B.G.; Albericio, F. Latest Advances on Synthesis, Purification, and Characterization of Peptides and Their Applications. Appl. Sci. 2021, 11, 5593. https://doi.org/10.3390/ app11125593

Received: 17 May 2021

Accepted: 15 June 2021

Published: 17 June 2021

Publisher's Note: MDPI stays neutral with regard to jurisdictional claims in published maps and institutional affiliations.

Copyright: (c) 2021 by the authors. Licensee MDPI, Basel, Switzerland. This article is an open access article distributed under the terms and conditions of the Creative Commons Attribution (CC BY) license (https:// creativecommons.org/licenses/by/ $4.0 /)$.
Peptides have a broad number of applications: from biochemical tools to diagnostic kits; from nanotechnology to new materials; and from vaccines to drugs. Increased interest in peptides in all these fields is exemplified by the growing number of peptide-based drugs available [1,2]. Table 1 shows the peptide drugs accepted by the US Food and Drug Administration (FDA) between Jan 2015 and May 2021 [3,4]. During these six and a half years, 21 peptide-based drugs have been launched onto the market. This number accounts for approximately $5 \%$ of the total number of drugs, including both new chemical entities and biologics, approved by the FDA in the same period. Importantly, although cancer and metabolism continue to be the main target, peptides are being used for a much wider spectrum of indications and they continue to gain applications with time (Table 1).

Table 1. Peptide-based drugs approved by the FDA (2015-2021 (May)) [4,5].

\begin{tabular}{|c|c|c|c|}
\hline Year & $\begin{array}{l}\text { Active Ingredient } \\
\text { Trade Name }\end{array}$ & Indication & Characteristics \\
\hline 2015 & $\begin{array}{l}\text { Insulin degludec } \\
\text { Tresiba }{ }^{\circledR}\end{array}$ & Diabetes & $\begin{array}{l}\text { Modified insulin with an aa } \\
\text { deletion and a hexadecanedioic } \\
\text { acid via } \gamma \text {-Glu at Lys (B29) }\end{array}$ \\
\hline 2015 & $\begin{array}{l}\text { Ixazomib }^{\circledR} \\
\text { Ninlar }^{\circledR}\end{array}$ & Multiple myeloma & $\begin{array}{l}N \text {-acylated, C-boronic acid } \\
\text { dipeptide }\end{array}$ \\
\hline 2016 & $\begin{array}{c}\text { Adlyxin } \\
\text { Lixisenatide }^{\circledR}\end{array}$ & Diabetes & $\begin{array}{l}44 \text { aa GLP-1 peptide with } \text { Lys }_{6} \text { at } \\
\text { the } C \text {-terminal }\end{array}$ \\
\hline 2017 & $\begin{array}{l}\text { Abaloparatide } \\
\text { Tymlos }^{\circledR}\end{array}$ & Osteoporosis & $\begin{array}{l}34 \text { aa analog of parathyroid } \\
\text { hormone-related protein }\end{array}$ \\
\hline 2017 & $\begin{array}{c}\text { Angiotensin II } \\
\text { Giapreza }^{\circledR}\end{array}$ & Hypotension & Natural octapeptide \\
\hline 2017 & $\begin{array}{l}\text { Etelcalcetide } \\
\text { Parsabiv }^{\circledR}\end{array}$ & Hyperparathyroidism & $\begin{array}{c}8 \text { aa in two Cys chains: Ac-DCys- } \\
\text { DAla-(DArg) } \text { ( }_{3} \text {-DAla-DArg- } \mathrm{NH}_{2} \\
\text { L-Cys }\end{array}$ \\
\hline 2017 & $\begin{array}{l}\text { Macimorelin } \\
\text { Macrilen }^{\circledR}\end{array}$ & $\begin{array}{l}\text { Growth hormone } \\
\text { deficiency }\end{array}$ & Pseudotripeptide $N$-formylated \\
\hline
\end{tabular}


Table 1. Cont.

\begin{tabular}{|c|c|c|c|}
\hline Year & $\begin{array}{l}\text { Active Ingredient } \\
\text { Trade Name }\end{array}$ & Indication & Characteristics \\
\hline 2017 & $\begin{array}{l}\text { Plecanatide } \\
\text { Trulance }^{\circledR}\end{array}$ & $\begin{array}{l}\text { Chronic idiopathic } \\
\text { constipation }\end{array}$ & 16 aa with two disulfides \\
\hline 2017 & $\begin{array}{l}\text { Semaglutide } \\
\text { Ozempic }{ }^{\circledR}\end{array}$ & Diabetes & $\begin{array}{l}\text { GLP-1 peptide ( } 31 \text { aa in the } \\
\text { chain) with hexadecanedioic acid } \\
\text { via } \gamma \text {-Glu and mini PEG at Lys }\end{array}$ \\
\hline 2018 & $\begin{array}{l}\text { 177Lu DOTA-TATE } \\
\text { Lutathera }^{\circledR}\end{array}$ & $\begin{array}{l}\text { Neuroendocrine } \\
\text { tumors, theranostics }\end{array}$ & $\begin{array}{l}\text { 177Lu chelated by DOTA bound } \\
\text { to Tyr3-octreotate }\end{array}$ \\
\hline 2019 & $\begin{array}{l}\text { Afamelanotide } \\
\text { Scenesse }{ }^{\circledR}\end{array}$ & $\begin{array}{l}\text { Skin damage and } \\
\text { pain }\end{array}$ & $\begin{array}{l}13 \text { aa linear peptide analog of } \\
\alpha-\mathrm{MSH}\end{array}$ \\
\hline 2019 & $\begin{array}{l}\text { Bremelanotide } \\
\text { Vyleesi }^{\circledR}\end{array}$ & $\begin{array}{l}\text { Hypoactive sexual } \\
\text { desire in women }\end{array}$ & $\begin{array}{c}7 \text { aa cyclic peptide analog of } \\
\alpha-\mathrm{MSH}\end{array}$ \\
\hline 2019 & $\begin{array}{l}\text { Enfortumab } \\
\text { Vedotin-Ejfv } \\
\text { PADCEV }^{\circledR}\end{array}$ & $\begin{array}{l}\text { Cancers expressing } \\
\text { nectin-4 }\end{array}$ & $\begin{array}{l}\text { ADC with a synthetic analog of } \\
\text { the marine natural peptide } \\
\text { dolastatin } 10 \text { ( } 5 \text { residues) }\end{array}$ \\
\hline 2019 & 68Ga DOTA-TOC & $\begin{array}{l}\text { Neuroendocrine } \\
\text { tumors, diagnostics }\end{array}$ & $\begin{array}{c}\text { 68Ga chelated by DOTA bound } \\
\text { to Tyr3-octreotide }\end{array}$ \\
\hline 2019 & $\begin{array}{c}\text { Polatuzumab } \\
\text { Vedotin-Piiq Polivy }\end{array}$ & $\begin{array}{l}\text { Diffuse large B-cell } \\
\text { lymphoma }\end{array}$ & $\begin{array}{l}\text { ADC with a synthetic analog of } \\
\text { dolastatin } 10 \text { ( } 5 \text { residues) }\end{array}$ \\
\hline 2020 & $\begin{array}{l}\text { Setmelanotide } \\
\text { Imcivree }^{\circledR}\end{array}$ & Obesity & 8 aa, cyclic disulfide \\
\hline 2020 & $\begin{array}{c}{ }^{64} \mathrm{Cu} \text {-DOTATATE } \\
\text { Detectnet }^{\circledR}\end{array}$ & Scintigraphic imaging & $\begin{array}{c}{ }^{64} \mathrm{Cu} \text { chelated by DOTA bound } \\
\text { to Tyr3-octreotate }\end{array}$ \\
\hline 2020 & ${ }^{68}$ Ga-PSMA-11 & $\begin{array}{l}\text { Diagnosis of } \\
\text { recurrent prostate } \\
\text { carcinoma }\end{array}$ & $\begin{array}{c}{ }^{68} \mathrm{Ga} \text { chelated by HBED-CC with } \\
\text { a pending urea-based } \\
\text { peptidomimetic }\end{array}$ \\
\hline 2020 & $\begin{array}{c}\text { Belantamab } \\
\text { mafodotin-blmf } \\
\text { Blenrep }^{\circledR}\end{array}$ & $\begin{array}{l}\text { Relapsed or refractory } \\
\text { multiple myeloma }\end{array}$ & $\begin{array}{l}\text { ADC with a synthetic analog of } \\
\text { the marine natural peptide } \\
\text { dolastatin } 10 \text { ( } 5 \text { residues) }\end{array}$ \\
\hline 2021 & $\begin{array}{l}\text { Voclosporin } \\
\text { Lupkynis }^{\circledR}\end{array}$ & Lupus nephritis & $\begin{array}{l}\text { Analog of cyclosporin, } 11 \text { aa } \\
\text { cyclic peptide with several } \\
\text { N-methyl aa }\end{array}$ \\
\hline 2021 & $\begin{array}{l}\text { Dasiglucagon } \\
\text { Zegalogue }^{\circledR}\end{array}$ & $\begin{array}{l}\text { Hypoglycemia in } \\
\text { individuals with } \\
\text { diabetes }\end{array}$ & 29 aa linear peptide \\
\hline
\end{tabular}

Only a few decades ago, it was unthinkable to consider producing an active pharmaceutical ingredient (API) of a chemical entity which requires more than seventy chemical steps—as in the case of Fuzeon ${ }^{\circledR}$ (enfurtivide, T20) [5] - fulfilling the requirements of the regulatory agencies, targeting both purity of the peptide API and identification of the impurities. This has been possible thanks to the breakthroughs in three fields: (i) chemical synthesis; (ii) purification; and (iii) characterization, which allowed consideration of peptides, and oligonucleotides too, as small molecules from purity and characterization points of view.

Coincidentally, at the same time, in the late fifties and early sixties, in the USA East Coast, Nobel Laureate R. Bruce Merrifield (Rockefeller University, New York) and the entrepreneur Jim Waters (Water Corporation, Milford, Massachusetts, USA) developed two techniques, for synthesis and purification, respectively, that over time proved to be crucial in making peptides and oligonucleotides (TIDES) an alternative to small molecules and biologics as drugs. Interestingly, the two techniques were based on a similar concept, namely the concourse of a solid support-a resin. 
Merrifield first envisaged and then implemented a solid polymeric protecting group for the $C$-terminal carboxylic group, in the so-called solid-phase peptide synthesis (SPPS) methodology [6]. Thus, the growing peptide chain can be elongated with $\mathrm{N}$-protected amino acids, while the peptide chain is in a pseudo-soluble state anchored to the solid support (resin). Thus, all reactions-coupling of the incoming residue and removal of the $\mathrm{N}$-protecting group - can be carried out using excesses of reagents, thus ensuring excellent yields. Intermediates are not isolated or characterized, and the excesses of reagents and soluble side products are removed by filtration and extensive washing with solvents. Once the sequence is completed, the unprotected peptide is cleaved from the resin. In recent years, resins, linkers, protecting groups, coupling reagents, solvents, and finally green approaches have been described for fine tuning the SPPS approach.

Reversed-phase high-performance liquid chromatography (RP-HPLC), whose roots are found in the pioneering work of Waters [7], is based on the hydrophobic interaction between the molecules-peptides in this case- to be purified in a hydrophilic mobile phase, and the hydrophobic moieties (long alkyl chains and others), which are attached to the solid support, the stationary phase. Jean Rivier linked SPPS and RP-HPLC [8]. Thus, using an analog of LH-RH as a peptide model, he showed that the synthesis of a peptide at industrial scale can be carried out using SPPS techniques, rendering a crude product with sufficient quality to be purified by RH-HPLC.

Mass spectrometry (MS) is probably the technique that has evolved most over time [9]. In combination with HPLC (separation by HPLC and detection by MS), it has become a key tool through which to detect and, more importantly, identify the chemical structure of the impurities present after synthesis. These impurities often have subtle structural changes that hinder their separation and identification. In this regard, they can contain one amino acid less or one more, deletion or double hit incorporation, respectively; they can be an epimer (racemization of just one residue) or a $\beta$-peptide (isomerization of Ser- or Asp); and the residues of Cys, Met, and Trp are able to undergo oxidation, or those of Cys, Met, Trp, and Tyr alkylation too [10].

The list of peptides that have reached the market (Table 1) supports the strength and the importance of these compounds in the pharmaceutical arena. In this context, we have decided to publish a Special Issue in Applied Sciences, entitled "Latest Advances on Synthesis, Purification, and Characterization of Peptides and their Applications", which provides excellent reviews and quality research articles covering the most recent developments in peptide synthesis, purification, and analysis. It is hoped that some of these new synthetic "tricks" will soon form part of the toolbox for the synthesis of peptides of therapeutic interest.

Author Contributions: A.E.-F., B.G.d.l.T. and F.A. equally contributed to writing the article. All authors have read and agreed to the published version of the manuscript.

Funding: The work in the laboratory of the authors was funded in part by the following: National Research Foundation (NRF) (Blue Skies Research Program \# 120386).

Conflicts of Interest: The authors declare no conflict of interest.

\section{References}

1. Muttenthaler, M.; King, G.F; Adams, D.J.; Alewood, P.F. Trends in peptide drug discovery. Nat. Rew. Drug. Discov. 2021, 20, 309-325. [CrossRef] [PubMed]

2. Al Musaimi, O.; Al Shaer, D.; Albericio, F.; de la Torre, B.G. 2020 FDA TIDES (Peptides and Oligonucleotides) Harvest. Pharmaceuticals 2021, 14, 145. [CrossRef] [PubMed]

3. de la Torre, B.G.; Albericio, F. Peptide Therapeutics 2.0. Molecules 2020, 25, 2293. [CrossRef] [PubMed]

4. FDA. Novel Drug Approvals for 2021. Available online: https://www.fda.gov/drugs/new-drugs-fda-cders-new-molecularentities-and-new-therapeutic-biological-products/novel-drug-approvals-2021 (accessed on 12 May 2021).

5. Bray, B.L. Large-scale manufacture of peptide therapeutics by chemical synthesis. Nat. Rew. Drug. Discov. 2003, 2, 587-593. [CrossRef] [PubMed]

6. Merrifield, R.B. Solid Phase Peptide Synthesis. I. The Synthesis of a Tetrapeptide. J. Am. Chem. Soc. 1963, 85, 2149-2154. [CrossRef] 
7. McDonald, P.D. James Waters and His Liquid Chromatography People: A Personal Perspective. In The Chromatographic Society Golden Jubilee Book: Recognising Half a Century of Supporting Progress in Separation Science; ILM: St Albans, UK, 2006. Available online: https:/ / www.waters.com/webassets/cms/library/docs/wa62008.pdf (accessed on 15 May 2021).

8. Hoeger, C.; Porter, J.; Boublik, J.; River, J. Preparative-scale synthesis and reversed-phase purification of a gonadotropin-releasing hormone antagonist. J. Chromatogr. 1989, 22, 307-318. [CrossRef]

9. Wysocki, V.H.; Resing, K.A.; Zhang, Q.; Cheng, G. Mass spectrometry of peptides and proteins. Methods 2005, 35, $211-222$. [CrossRef] [PubMed]

10. Yang, Y. Side Reactions on Amino Groups in Peptide Synthesis. In Side Reactions in Peptide Synthesis; Academic Press: Oxford, UK, 2016; ISBN 978-0-12-801009-9. 